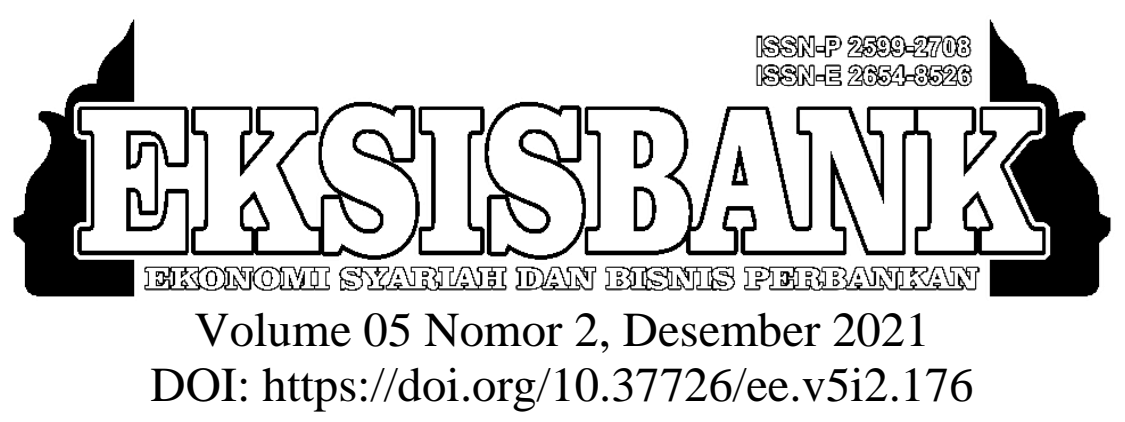

\title{
Pengaruh Pembiayaan Musyarakah Terhadap Pendapatan Bank BRI Syariah Indonesia Periode 2014-2020
}

\author{
Noorulviah Beredhawati Atmaja ${ }^{1}$, Siti Amallia Tadim², R. Deden Adhianto ${ }^{3}$ \\ ${ }^{123}$ Politeknik Piksi Ganesha Bandung \\ Jl. Jend. Gatot Subroto No. 301 Bandung 40274 Indonesia \\ ${ }^{1}$ rdha558@gmail.com \\ ${ }^{2}$ sitiamalliatadim15@gmail.com \\ 3adhiantogd@yahoo.com
}

\begin{abstract}
ABSTRAK
Pembiayaan konsumer menjadi salah satu fokus penyaluran pembiayaan BRI Syariah karena memiliki risiko yang rendah. Hal ini dikarenakan pembiayaan konsumer ini berdasarkan KPR dan pembiayaan multi guna. Penelitian ini bertujuan untuk mengetahui Pengaruh Pembiayaan Musyarakah Terhadap Pendapatan. Penelitian ini dilakukan pada Bank BRI Syariah Indonesia periode 2014 sampai 2020. Metode ini menggunakan deskriptif pendekatan kuantitatif. Perkembangan perbankan syariah ini ditandai pula dengan peningkatan penyaluran pembiayaan. Pembiayaan menjadi sangat penting karena faktor pembiayaan inilah yang menjadi kunci perkembangan bank syariah dimasa mendatang. Idealnya pembiayaan bank syariah didominasi oleh akad musyarakah yang dijalankan dengan sistem bagi hasil. Data yang digunakan dalam penelitian ini adalah data sekunder yang berasal dari annual report yang dapat diakses melalui website Otoritas Jasa Keuangan dalam bentuk deret waktu pertahun dari 20142020. Penelitian ini menerapkan metode analisis data regresi linear sederhana. Berdasarkan hasil penelitian dengan menggunakan program statistik SPSS Version 20, Pembiayaan Musyarakah (X) berpengaruh positif dan signifikan terhadap Pendapatan (Y).
\end{abstract}

Kata kunci - Pembiayaan Musyarakah, Pendapatan Bank, BRIS

\section{ABSTRACT}

Consumer financing is one of the focuses of BRI Syariah financing distribution because it has a low risk. This is because consumer financing is based on mortgages and multi-purpose financing. This study aims to determine the effect of Musyarakah Financing on Income. This research was conducted at Bank BRI Syariah Indonesia for the period 2014 to 2020. This method uses a descriptive quantitative approach. The development of Islamic banking is also

EKSISBANK (Ekonomi Syariah dan Bisnis Perbankan), Volume 5, Nomor 2, Desember 2021 
marked by an increase in the distribution of financing. Financing is very important because this financing factor is the key to the development of Islamic banks in the future. Ideally, Islamic bank financing is dominated by musharaka contracts which are run with a profitsharing system. The data used in this study is secondary data derived from annual reports that can be accessed through the Financial Services Authority website in the form of an annual time series from 2014-2020. This study applies a simple linear regression data analysis method. Based on the results of research using the SPSS Version 20 statistical program, Musyarakah Financing (X) has a positive and significant effect on Income (Y).

Keywords - Musyarakah Financing, Bank Income, BRIS

\section{PENDAHULUAN}

Bank syariah di Indonesia lahir sejak 1992. Secara kelembagaan bank syariah pertama kali yang berdiri di Indonesia adalah Bank Muamalat Indonesia (BMI), kemudian baru menyusul bank-bank lain yang membuka jendela syariah dalam menjalankan kegiatan usahanya. Melalui jendela syariah ini, bankbank konvensional dapat memberikan jasa pembiayaan syariah kepada para nasabahnya mlalui produk-produk yang bebas dari unsur riba, gharar, dan maytsir dengan terlebih dahulu membentuk Unit Usaha Syariah (UUS). UUS adalah unit kerja di kantor pusat bank umum konvensional yang berfungsi sebagai kantor induk dari kantor cabang syariah dan atau unit syariah.

Perkembangan perbankan syariah ini ditandai pula dengan peningkatan penyaluran pembiayaan. Pembiayaan menjadi sangat penting karena faktor pembiayaan inilah yang menjadi kunci perkembangan bank syariah dimasa mendatang. Idealnya pembiayaan bank syariah didominasi oleh akad musyarakah yang dijalankan dengan sistem bagi hasil.

Pembiayaan musyarakah telah difatwakan oleh Fatwa DSN-MUI No. 08/DSNMUI/IV/2000 Tentang Pembiayaan Musyarakah yang menimbang "bahwa kebutuhan masyarakat untuk meningkatkan kesejahteraan dan usaha terkadang memrlukan dana dari pihak lain, antara lain melalui pembiayaan musyarakah, yaitu pembiayaan yang berdasarkan akad kerjasama antara dua pihak atau lebih untuk suatu usaha tertentu, dimana masing-masing pihak memberikan kontribusi dana dengan ketentuan bahwa keuntungan dan resiko akan ditanggung bersama sesuai dengan kesepakatan".

Bank Rakyat Indonesia Syariah (BRI Syariah) merupakan sebuah bank ritel modern terkemuka dengan layanan finansial berdasarkan kebutuhan nasabah dengan jangkauan termudah untuk kehidupan yang lebih bermakna. BRI Syariah melayani nasabah dengan pelayanan prima dan menawarkan beraneka produk yang sesuai dengan harapan nasabah dengan prinsip syariah.

Pembiayaan konsumer ini menjadi salah satu fokus penyaluran pembiayaan BRI Syariah karena memiliki risiko yang rendah. Hal ini dikarenakan pembiayaan konsumer ini berdasarkan KPR dan pembiayaan multi guna. Tabel 1.1

Pembiayaan Musyarakah dan Pendapatan Bank BRI Syariah Indonesia periode 20142020

\begin{tabular}{|c|c|c|}
\hline Tahun & Pembiayaan Musyarakah & Pendapatan \\
\hline 2014 & 4.005 .308 & 1.145 .232 \\
\hline 2015 & 4.962 .346 & 1.527 .770 \\
\hline 2016 & 5.185 .890 & 1.726 .667 \\
\hline 2017 & 5.447 .998 & 1.771 .609 \\
\hline 2018 & 7.406 .955 & 1.997 .389 \\
\hline 2019 & 11.019 .873 & 2.304 .500 \\
\hline 2020 & 14.171 .405 & 3.249 .115 \\
\hline
\end{tabular}

EKSISBANK (Ekonomi Syariah dan Bisnis Perbankan), Volume 5, Nomor 2, Desember 2021 http://journal.sties-purwakarta.ac.id/index.php/EKSISBANK/ ISSN: 2654-8526 (Media Online) 2599-2708 (Media Cetak) 
Sumber : Laporan Tahunan BRI Syariah Indonesia, 2021

Grafik 1.1

Grafik Perkembangan Pembiayaan Musyarakah Bank Bri Syariah Indonesia Periode 2014-2020

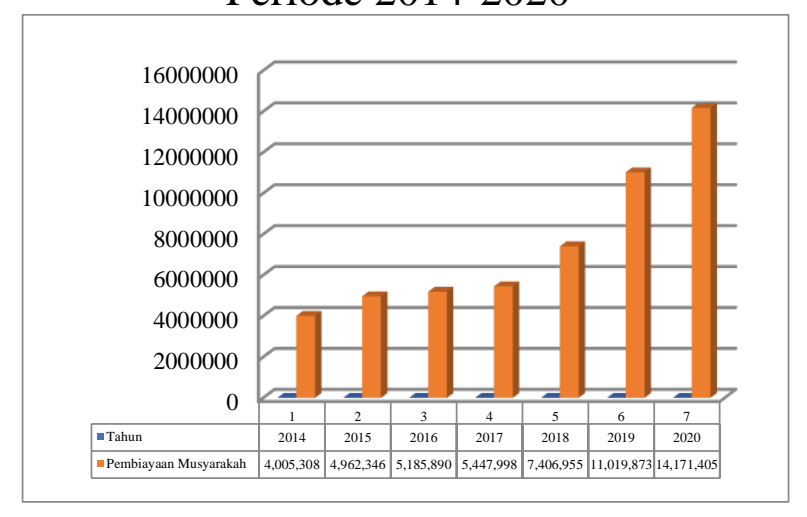

Berdasarkan dari grafik diatas Pembiayaan Musyarakah setiap tahunnya mengalami kenaikan. Pada tahun 2014 sebesar Rp. 4.005.308, tahun 2015 sebesar Rp. 4.962.346, tahun 2016 sebesar 5.185.890, tahun 2017 sebesar 5.447.998, tahun 2018 sebesar 7.406.995, tahun 2019 sebesar 11.019.873, dan tahun 2020 sebesar 14.171.405.

\section{Grafik 1.2}

Grafik Perkembangan Pendapatan Bank Syariah Indonesia 2014-2020

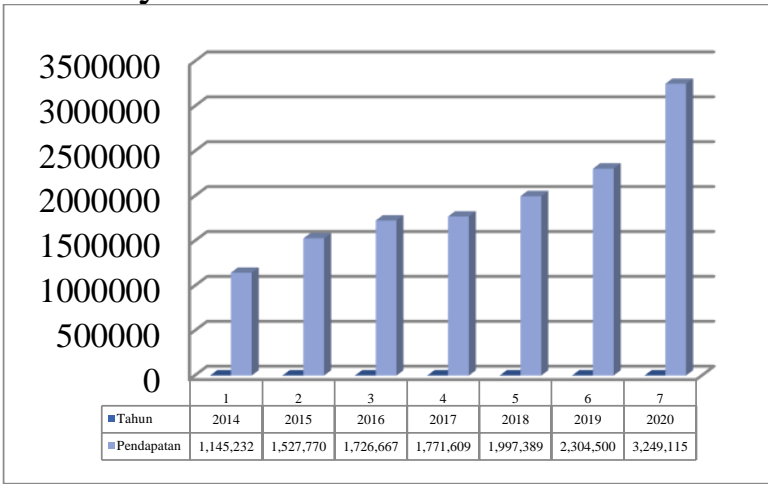

Pada tahun 2020 laporan keuangan Bank BRI Syariah terus mengalami peningkatan. Diketahui peningkatan persentase jumlah pendapatan pada tahun 2014-2018 sebesar $11.62 \%$ dan pada tahun 2016-2020 mengalami peningkatan menjadi $40.99 \%$.
Pembiayaan konsumer menjadi salah satu fokus penyaluran pembiayaan BRI Syariah karena memiliki risiko yang rendah. Hal ini dikarenakan pembiayaan konsumer ini berdasarkan KPR dan pembiayaan multi guna.

Berdasarkan latar belakang yang telah dikemukakan diatas, maka tujuan penelitian ini adalah untuk mengetahui apakah pembiayaan musyarakah berpengaruh terhadap pendapatan Bank BRI Syariah Indonesia periode 2014-2020.

\section{A. Kajian Teori}

\section{TINJAUAN PUSTAKA}

\section{Pengertian Pembiayaan Musyarakah}

Musyarakah adalah akad kerja sama antara dua pihak atau lebih untuk suatu usaha tertentu dimana masing-masing pihak memberikan kontribusi dana dengan kesepakatan bahwa keuntungan dan risiko akan ditanggung bersama sesuai kesepakatan.

Musyarakah merupakan suatu metode yang didasarkan pada keikutserataan bank dan pencari pembiayaan (mitra potensial) untuk suatu proyek tertentu, dan akhirnya keikutsertaan dalam menghasilkan laba dan rugi (Asiyah, 2019).

Dalam perbankan syariah musyarakah merupakan mekanisme kerja (akumulasi kerja dan modal) yang memberikan manfaat bagi masyarakat luas dalam produksi barang maupun pelayanan terhadap kebutuhan masyarakat (Rohmi, 2020).

Pembiayaan musyarakah adalah kerjasama dimana dua atau lebih pengusaha bekerjasama sebagai mitra usaha dalam bisnis. Masingmasing pihak menyertakan modalnya dan ikut mengelola usaha tersebut. Keuntungan dan kerugian akan dibagi berdasarkan persentase penyertaan modalnya (Destiana, 2016).

Adapun bentuk pembiayaan musyarakah yang digunakan bank Islam meliputi musyarakah untuk perdagangan (comercial musyarakah), keikutsertaan untuk sementara 
(descreasing partisipation), keikutsertaan untuk selamanya (permanent partisipation).

\section{Dasar Hukum}

1. Al-Qur'an Surat Shad ayat 24 :

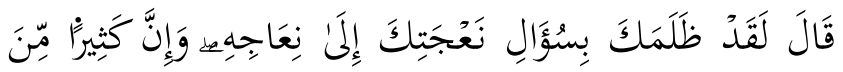

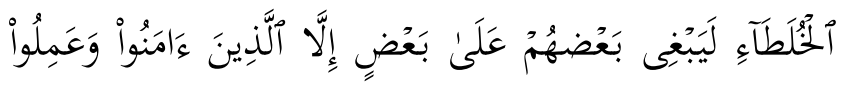

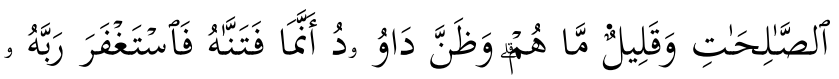
وَخَرَّ رَاكِعًا وَأَنَابَ

Artinya : "Daud berkata: "Sesungguhnya dia telah berbuat zalim kepadamu dengan meminta kambingmu itu untuk ditambahkan kepada kambingnya. Dan sesungguhnya kebanyakan dari orang-orang yang berserikat itu sebahagian mereka berbuat zalim kepada sebahagian yang lain, kecuali orang orang yang beriman dan mengerjakan amal yang saleh; dan amat sedikitlah mereka ini". Dan Daud mengetahui bahwa Kami mengujinya; maka ia meminta ampun kepada Tuhannya lalu menyungkur sujud dan bertaubat" (Q.S Shad ayat 24)

2. Hadist Riwayat Abu Daud dari Abu Hurairah :

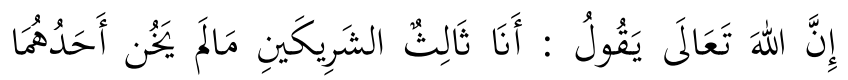

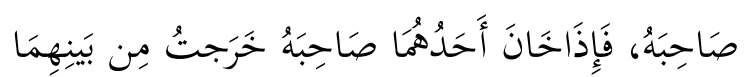

Artinya : "Allah swt. berfirman: 'Aku adalah pihak ketiga dari dua orang yang bersyarikat selama salah satu pihak tidak mengkhianati pihak yang lain. Jika salah satu pihak telah berkhianat, Aku keluar dari mereka." (HR. Abu Daud, yang dishahihkan oleh Al-Hakim, dari Abu Hurairah).

3. Fatwa DSN-MUI

Fatwa DSN-MUI No. 08/DSNMUI/IV/2000 Tentang Pembiayaan Musyarakah

a) Keuntungan harus dikuantifikasi dengan jelas untuk menghindarkan perbedaan dan sengketa pada waktu alokasi keuntungan atau penghentian musyarakah. b) Setiap keuntungan mitra harus dibagikan secara proposional atas dasar seluruh keuntungan dan tidak ada jumlah yang ditentukan diawal yang ditetapkan bagi seorang mitra.

c) Seorang mitra boleh mengusulkan bahwa jika keuntungan melebihi jumlah tertentu, kelebihan atau prosentase itu diberikan kepadanya.

d) Sistem pembagian keuntungan harus tertuang dengan jelas dalam akad.

4. Rukun dan Syarat Musyarakah

Rukun dari akad musyarakah yang harus dipenuhi dalam transaksi ada beberapa, yaitu :

a) Pelaku akad, yaotu para mitra usaha

b) Obbjek akad, yaitu modal (mal), kerja (dharabah), dan keuntungan (ribh)

c) Shigat, yaitu ijab dan qabul

Syarat-syarat yang berhubungan dengan syirkah dapat dibagi menjadi syarat yang berlaku umum dan syarat khusus pada jenis syirkah tertentu.

Sesuatu yang bertalian dengan semua bentuk syirkah baik dengan harta maupun dengan yang lainnya. Dalam hal ini terdapat dua syarat, yaitu: a) yang berkenaan dengan benda yang diakadkan adalah harus dapat diterima sebagai perwakilan, b) yang berkenaan dengan keuntungan, yaitu pembagian keuntungan harus jelas dan dapat diketahui dua pihak, misalnya setengah, sepertiga, dan yang lainnya (Hidayatullah, 2020).

\section{Jenis-Jenis Musyarakah}

1. Musyarakah kepemilikan

Musyarakah pemilikan tercipta karena warisan, wasiat atau kondisi lainnya yang mengakibatkan pemilikan satu aset oleh dua orang atau lebih berbagi dalam sebuah aset nyata dan berbagu pula dari keuntungan yang dihasilkan dari aset tersebut.

2. Musyarakah akad

EKSISBANK (Ekonomi Syariah dan Bisnis Perbankan), Volume 5, Nomor 2, Desember 2021 http://journal.sties-purwakarta.ac.id/index.php/EKSISBANK/ 
Musyarakah akad tercipta dengan cara kesepakatan dimana dua orang atau lebih setuju bahwa tiap orang dari mereka memberikan modal musyarakah. Merekapun sepakat berbagi keuntungan dan kerugian. Musyarakah akad terdiri menjadi al-i'nan, almufawadhah, al-a'maal, al-wujuh, dan almudharabah (Asiyah, 2019).

Musyarakah dalam konteks perbankan berarti perjanjian kesepakatan bersama antara beberapa pemilik modal untuk menyertakan modal sahamnya pada suatu proyek. Sebagai yang mengoperasikan uang untuk modal, maka dapat dipastikan musyarakah yang digunakan ialah syirkah al-mal yakn syirkah al-inan dan syirkah al-mufawadhah (Chefi Abdul Latif, 2020).

Pembiayaan konsumer ini menjadi salah satu fokus penyaluran pembiayaan BRI Syariah karena memiliki risiko yang rendah. Hal ini dikarenakan pembiayaan konsumer ini berdasarkan KPR dan pembiayaan multi guna.

\section{Manfaat Musyarakah}

1. Bank akan menikmati peningkatan jumlah dalam tertentu pada saat keuntungan usaha nasabah meningkat.

2. Bank tidak berkewajiban membayar dalam jumlah tertentu kepada nasabah pendanaan secara tetap, tetapi disesuaikan dengan pendapatan atau hasil usaha bank, sehingga bank tidak akan pernah mengalami negative spread.

3. Pengembalian pokok pembiayaan disesuaikan dengan arus kas usaha nasabah, sehingga tidak memberatkan nasabah.

4. Bank akan selektif dan hati-hati mencari usaha yang benar-benar halal, aman, dan menguntungkan. Hal ini karena keuntungan yang riil dan benar-benar terjadi itu yang akan dibagikan.

5. Prinsip bagi hasil dalam musyarakah ini berbeda dengan prinsip bunga tetap dimana bank akan menagih penerima pembiayaan (nasabah) satu jumlah bunga tetap berapa pun keuntungan yang dihasilkan nasabah, bahkan sekalipun merugi dan terjadi krisis ekonomi (Antonio, 2001).

\section{Pendapatan}

1. Pengertian Pendapatan

Pendapatan adalah pendapatan riil yaitu pendapatan yang sebenarnya diperoleh bank dari hasil investasi aset produktif, baik itu pendapatan margin, pendapatan rasio, atau pendapatan sewa (Wahyuningsih, 2018).

Santoso menyatakan bahwa pendapatan adalah masuknya atau bertambahanya aktiva atau penyelesaian suatu kewajiban atau kombinasi dari keduanya yang diperoleh dari penyerahan atau produksi barang, pemberian jasa atau kegiatan lain yang merupakan operasi utama atau operasi inti (major/central operation) yang berkelanjutan (regular) dari suatu perusahaan.

Menurut Skousen dan Stice menyatakan pendapatan adalah arus masuk atau peningkatan aktiva lainnya sebuah entitas atau pembentukan utang ( atau sebuah kombinasi dari keduanya ) dari pengantaran barang atau penghasilan barang, memberikan pelayanan atau melakukan aktivitas lain yang membentuk operasi pokok atau bentuk entitas yang terus berlangsung.

2. Sumber dan Jenis Pendapatan

Pada dasarnya pendapatan berasal dari penjualan barang atau pemberian jasa kepada pihak lain Dalam periode akuntansi tertentu. Pendapatan dapat berasal dari penjualan, proses produksi, dan penyediaan jasa Termasuk proses pengangkutan dan penyimpanan (revenue process). Di perusahaan perdagangan, pendapatan Dihasilkan dari penjualan barang. Di perusahaan manufaktur, pendapatan berasal dari penjualan produk Lengkap. Bagi 
perusahaan jasa, pendapatan diperoleh dengan memberikan jasa kepada pihak lain.

Adapun jenis-jenis pendapatan dari satu kegiatan perusahaan adalah sebagai berikut :

1. Pendapatan operasional

Menurut Dyckman, Dukes dan Davis pada dasarnya pendapatan operasional timbul dari berbagai cara yaitu :

2. Pendapatan yang diperoleh dari kegiatan usaha yang dilaksanakan sendiri oleh perusahaan tersebut tanpa penyerahan jasa yang telah selesai diproduksi.

3. Pendapatan yang diperoleh dari kegiatan usaha dengan adanya hubungan yang telah disetujui, misalnya penjualan konsinyasi.

4. Pendapatan dari kegiatan usaha yang dilaksanakan melalui kerja sama dengan para investor.

5. Pendapatan non operasional (pendapatan lain-lain)

Pendapatan yang diperoleh dari sumber lain diluar kegiatan utama perusahaan digolongkan sebagai pendapatan non operasional yang sering juga disebut sebagai pendapatan lain-lain. investasi.Pada umum nya sumber dan jenis pendapatan dapat dikelompokkan sebagai berikut :

1. Pendapatan dari Operasi Normal Perusahaan.

2. Pendapatan dari Luar Operasi Perusahaan (Lumingkewas, 2013).

\section{B. Perbandingan Penelitian Terdahulu}

Penelitian tentang pembiayaan musyarakah terhadap pendapatan bank sudah banyak dilakukan oleh peneliti sebelumnya, salah satunya sebagai berikut :

1. Pengaruh Pembiayaan Murabahah, Pembiayaan Musyarakah, Pembiayaan Qardh Terhadap Profitabilitas (Jamaludin et al., 2021)

Penelitian ini bertujuan untuk mengetahui pengaruh pembiayaan Murabahah,
Pembiayaan Musyarakah, dan Pembiayaan Qardh terhadap profitabilitas. Penelitian ini dilakukan dengan menggunakan metode kuantitatif dengan pendekatan assosiatif. Populasi dalam penelitian ini adalah laporan keuangan Bank Umum Syariah pertriwulan periode 2016-2019 sebanyak Empat Bank Umum Syariah dan diambil 64 sampel laporan keuangan. Dalam penelitian ini pengambilan sampel dengan teknik purposive sampling. Teknik pengumpulan data yang digunakan yaitu menggunakan data sekunder. Teknik analisis data yang digunakan adalah uji asumsi klasik, analisis linear berganda dan uji hipotesis.

Hasil penelitian ini menunjukkan bahwa secara parsial Pembiayaan Murabahah tidak berpengaruh signifikan terhadap profitabilitas Sementara untuk Pembiayaan Musyarakah berpengaruh negatif signifikan secara parsial terhadap profitabilitas dan pembiayaan Qardh berpengaruh signifikan secara parsial terhadap profitabilitas. Sementara secara simultan pembiayaan Murabahah, Pembiayaan Musyarakah, Pembiayaan Qardh bepengaruh signifikan terhadap profitabilitas.

Perbandingan penelitian sebelumnya dengan saat ini adalah penelitian sebelumnya menggunakan metode kuantitatif dengan pendekatan assosiatif. Sedangkan penelitian saat ini menggunakan metode kuatitatif dengan pendekatan deskriptif.

2. Pengaruh Pembiayaan Mudharabah, Musyarakah, Murabahah, dan Ijarah Terhadap Profitabilitas 4 Bank Umum Syariah Periode 2014-2016 (Putra, 2018)

Penelitian ini bertujuan untuk mengetahui pengaruh pembiayaan mudharabah, musyarakah, murabahah, dan ijarah terhadap profitabilitas Bank Umum Syariah yang terdaftar di Bank Indonesia Periode 20132016. Data yang digunakan adalah laporan keuangan Bank Umum Syariah (BUS) yang 
terdaftar di Bank Indonesia. Data dianalisis menggunakan regresi linear berganda. Sampel dalam penelitian ini sebanyak 4 Bank Umum Syariah, yang menyediakan laporan keuangan per triwulan. Sampel diambil menggunakan teknik pengambilan purposive sampling. Hasil dari penelitian ini menunjukkan secara parsial bahwa pembiayaan mudharabah tidak berpengaruh, pembiayaan musyarakah berpengaruh negatif signifikan, pembiayaan murabahah berpengaruh positif signifikan, pembiayaan ijarah berpengaruh positif signifikan terhadap profitabilitas ROE. Sedangkan secara simultan pembiayaan mudharabah, musyarakah, murabahah dan ijarah berpengaruh positif signifikan terhadap profitabilitas.

Perbandingan penelitian sebelumnya dengan saat ini adalah penelitian sebelumnya menganalisis sebanyak 4 sampel Bank Umum Syariah dengan hasil dari penelitian menunjukkan secara parsial bahwa pembiayaan mudharabah tidak berpengaruh, pembiayaan musyarakah berpengaruh negatif signifikan, pembiayaan murabahah berpengaruh positif signifikan, pembiayaan ijarah berpengaruh positif signifikan terhadap profitabilitas ROE.

Sedangkan penelitian saat ini hanya menganalisis di Bank BRI Syariah Indonesia dengan hasil menunjukkan bahwa pembiayaan musyarakah berpengaruh positif signifikan terhadap pendapatan pada Bank BRI Syariah.

3. Pembiayaan Mudharabah dan Pembiayaan Musyarakah di Perbankan Syariah (Destiana, 2016)

Mudharabah adalah akad kerja sama pemilik modal dan pengelola modal dimana keuntungan dan kerugian dibagi berdasarkan kesepakatan oleh beberapa pihak yang terlibat. Musyarakah adalah akad kerjasama dua pihak atau lebih untuk berserikat dalam modal serta keuntungan dan kerugian yang diperoleh dibagi berdasarkan kesepakatan secara proporsional. Dasar hukum pembiayaan mudharabah dan pembiayaan musyarakah ada dalam al-Quran, Hadist, dan Ijma ${ }^{e e}$. Produk hukum yang mengatur kedua pembiayaan tersebut yaitu Perundang-undangan, Peraturan Bank Indonesia, Fatwa DSN MUI. Sebelum melaksanakan akad pembiayaan mudharabah dan musyarakah perlu diketahui dan diaktualisasikannya syarat dan rukun daripada kedua pembiayaan tersebut. Pembiayaan mudharabah terbagi menjadi dua bagian yaitu mudharabah muthlaqah dan mudharabah muqayyadah sedangkan Pembiayaan musyarakah terbagi kepada dua bagian, yaitu syirkah al-amlak dan syirkah al„uqud. Syirkah al-amlak terdiri dari, yaitu syirkah al-jabr dan syirkah al-ikhtiyar. Sedangkan syirkah al-,,uqud terdiri dari empat jenis, yaitu syirkah al-mufawadhah, syirkah al-,,inan, syirkah al-wujuh, syirkah al-,,amal, dan syirkah mudharabah. Impelementasi pembiayaan mudharabah dan pembiayaan musyarakah diperbankan syariah sudah berkembang dan lengkap sesuai dengan peraturan perbankan syariah.

Perbandingan penelitian ini dengan sebelumnya adalah penelitian sebelumnya berfokus pada 2 pembiayaan, yaitu pembiayaan mudharabah dan pembiayaan musyarakah. Sedangkan penelitian ini lebih berfokus pada pembiayaan musyarakah.

4. Pengaruh Pembiayaan Mudharabah dan Musyarakah Terhadap Profitabilitas (ROA) Pada BPRS HIK Bekasi Kantor Cabang Karawang (Nawawi \& Nurdiansyah, 2018) Tujuan penelitian ini untuk menganalisis pengaruh pembiayaan mudharabah dan musyarakah terhadap profitabilitas (ROA) pada BPRS HIK Bekasi Kantor Cabang Karawang. Metode penelitian menggunakan metode deskriptif 
kuantitatif dengan populasi adalah semua laporan keuangan Triwulan BPRS HIK Bekasi Kantor Cabang Karawang. Hasil penelitian yang dilakukan menunjukkan bahwa : (1) pembiayaan mudharabah berpengaruh positif dan tidak signifikan terhadap profitabilitas Return on Assets (ROA) BPRS HIK Bekasi Kantor Cabang Karawang periode 2009-2016 secara parsial. Hal tersebut dibuktikan dengan nilai sig. $0.187>0,05$ dan nilai t hitung yakni $1,351<\mathrm{t}$ tabel 2,042. (2) Pembiayaan musyarakah berpengaruh negatif signifikan terhadap profitabilitas Return on Assets (ROA) BPRS HIK Bekasi Kantor Cabang Karawang periode 2009-2016 secara parsial. Hal tersebut dibuktikan dengan sig. $0.000<0,05$ dan nilai $\mathrm{t}$ hitung yakni -7,560 >t tabel 2,042. (3) Pembiayaan mudharabah dan pembiayaan musyarakah berpengaruh signifikan terhadap profitabilitas Return on Assets (ROA) BPRS HIK Bekasi Kantor Cabang Karawang periode 2009-2016 secara simultan. Hal tersebut dibuktikan dengan nilai sig. 0.000 $<0,05$ dan nilai f hitung yakni 31,022 > f tabel 3,32.

Perbandingan penelitian sebelumnya dengan saat ini adalah penelitian sebelumnya menggunakan 3 variabel Pembiayaan Mudharabah (X1), Musyarakah (X2), dan Profitabilitas (Y) dengan lokasi penelitian yang berbeda dan hasil penelitian dari peneliti sebelumnya menunjukkan pembiayaan musyarakah berpengaruh negatif signifikan terhadap profitabilitas. Sedangkan penelitian ini menggunakan 2 variabel Pembiayaan Musyarakah (X) dan Pendapatan (Y) dengan menunjukkan pembiayaan Musyarakah berpengaruh positif signifikan terhadap pendapatan.

5. Pengaruh Pembiayaan Mudharabah, Pembiayaan Musyarakah dan Sewa Ijarah
Terhadap Profitabilitas (Ditha Nada Pratama, Lia Dwi Martika, 2017)

Penelitian ini bertujuan untuk mengetahui pengaruh Pembiayaan Mudharabah, Pembiayaan Musyarakah dan Sewa Ijarah baik secara parsial maupun secara bersama sama terhadap Tingkat Profitabilitas pada PT. Bank Muamalat Indonesia, Tbk. Metode penelitian yang digunakan dalam penelitian ini yaitu metode deskriptif dan verifikatif dengan pendekatan kuantitatif. Penelitian ini menggunakan model analisis Regresi linier Berganda, dengan menggunakan empat asumsi klasik yaitu normalitas, multikolinearitas, autokorelasi dan heteroskedastisitas. Berdasarkan hasil penelitian dengan menggunakan program statistik SPSS Versions 20, dengan menggunakan analisis regresi berganda, untuk Pembiayaan Mudharabah diperoleh kesimpulan bahwa Pembiayaan Mudharabah (X1) berpengaruh positif dan signifikan terhadap tingkat Tingkat Profitabilitas (Y). Selanjutnya untuk Pembiayaan Musyarakah diperoleh kesimpulan bahwa Pembiayaan Musyarakah (X2) berpengaruh positif dan signifikan terhadap tingkat Profitabilitas. Kemudian untuk Sewa Ijarah diperoleh kesimpulan bahwa Sewa Ijarah (X3) berpengaruh positif dan signifikan terhadap Tingkat Profitabilitas (Y). Secara bersamasama diperoleh kesimpulan bahwa Pembiayaan Mudharabah(X1), Pembiayaan Musyarakah (X2) dan Sewa Ijarah (X3) secara bersama sama berpengaruh signifikan terhadap Tingkat Profitabilitas (Y).

Perbandingan penelitan sebelumnya dengan saat ini adalah peneliti sebelumnya menggunakan 4 variabel yaitu Pembiayaan Mudharabah (X1), Pembiayaan Musyarakah (X2), Sewa Ijarah (X3), dan Profitabilitas (Y). Sedangkan peneliti ini hanya menggunakan 2 variabel yaitu Pembiayaan Musyarakah (X) dan Pendapatan (Y). 
6. Pengaruh Pembiayaan Murabahah, Pembiayaan Mudharabah dan Pembiayaan Musyarakag Terhadap Profitabilitas (Sari \& Sulaeman, 2021)

Penelitian ini bertujuan untuk mengetahui pengaruh pembiayaan murabahah, pembiayaan mudharabah dan pembiayaan musyarakah terhadap tingkat profitabilitas. Penelitian ini dilakukan dengan menggunakan metode kuantitatif dengan pendekatan asosiatif. Objek dalam penelitian ini adalah laporan keuangan Bank Umum Syariah pertriwulan periode 2016-2019 sebanyak Tiga Bank Umum Syariah dan diambil sampel 48 laporan keuangan. Dalam penelitian ini pengambilan sempel dengan teknik purposive sampling. Teknik pengumpulan datanya dengan menggunakan data skunder. Teknik analisis data yang digunakan adalah uji asumsi klasik, analisis linear berganda, dan uji hipotesis. Hasil penelitian ini menunjukan bahwa pembiayaan murabahah berpengaruh positif terhadap ROA dengan tingkat signifikan 0,000. Pembiayaan mudharabah berpengaruh positif terhadap ROA dengan tingkat signifikan 0,000 . Sedangkan untuk pembiayaan musyarakah tidak berpengaruh positif terhadap ROA dengan tingkat signifikansi 0,000. Sedangkan secara simultan Pembiayaan murabahah, pembiayaan Mudharabah dan Pembiayaan Musyarakah berpengaruh sebesar $91 \%$ terhadap tingkat Profitabilitas pada Bank Umum Syariah di Indonesia periode 2016 2019, yang sisanya 9\% dipengaruhi oleh faktor-faktor lainnya yang tidak diteliti oleh penulis dalam penelitian ini.

Perbandingan penelitian sebelumnya dengan saat ini adalah penelitian sebelumnya meneliti 3 Pembiayaan (Pembiayaan Murabahah, Pembiayaan Mudharabah, Pembiayaan Musyarakah) terhadap Profitabilitas, menggunakan teknik analisis linear berganda dengan hasil pembiayaan musyarakah tidak berpengaruh positif terhadap tingkat propitabilitas. Sedangkan peneliti ini hanya meneliti 1 pembiayaan (Pembiayaan Musyarakah) terhadap Pendapatan menggunakan teknik analisis liear sederhana dengan hasil pembiayaan musyarakah berpengaruh positif signifikan terhadap pendapatan.

\section{Analisis Dana Pihak Ketiga dan Risiko} Terhadap Pembiayaan (Destiana, 2016)

Pembiayaan mudharabah dan musyarakah termasuk ke dalam pembiayaan dengan prinsip bagi hasil. Pembiayaan mudharabah dan musyarakah lebih menyentuh pada sektor riil dan menggerakkan perekonomian. Penelitian ini bertujuan untuk menguji dan menganalisis pengaruh dana pihak ketiga dan risiko terhadap pembiayaan mudharabah dan musyarakah pada bank syariah di Indonesia. Penelitian ini menggunakan pendekatan kuantitatif. Data yang digunakan adalah data sekunder yang diperoleh dari Statistik Perbankan Syariah yang dipublikasikan dalam situs resmi Bank Indonesia. Data yang disajikan dalam Statistik Perbankan Syariah tersebut bersumber dari laporan bulanan bank umum syariah (BUS) sehingga data penelitian ini merupakan data gabungan BUS dan unit usaha syariah (UUS) yang terdaftar di Bank Indonesia. Data kemudian dianalisis menggunakan analisis regresi berganda. Hipotesis penelitian diuji menggunakan uji t. Hasil penelitian menunjukkan bahwa baik $\%$ DPK maupun risiko, kedua-duanya berpengaruh positif terhadap pembiayaan mudharabah dan musyarakah pada bank syariah di Indonesia.

Perbedaan penelitian terdahulu dengan penelitian ini terletak pada judul yaitu penelitian sebelumnya adalah Analisis Dana Pihak Ketiga dan Risiko Terhadap Pembiayaan. Sedangkan penelitian ini 
Pengaruh Pembiayaan Musyarakah terhadap Pendapatan Pada Bank BRI Syariah Indonesia.

\section{METODE PENELITIAN}

Jenis penelitian ini adalah penelitian deskriptif pendekatan kuantitatif untuk menganalisa pembiayaan musyarakah pada Bank BRI Syariah Indonesia.

Metode analisis deskriptif yang dipakai dalam penelitian ini, yang merupakan wujud analisa yang menguji keseluruhan hasil dari suatu penelitian dengan menggunakan satu sampel (Fikri, 2021).

Dalam hal ini penulis memakai metode kuantitatif dan Jenis data dalam penelitian ini adalah data sekunder dalam bentuk time series. Populasi yang dipakai yaitu suatu laporan keuangan berdasarkan triwulan pada Bank Muamalat Indonesia periode 2012-2019 dimana total menjadi 32 laporan keuangan selama 8 tahun. Pemilihan sampel memakai sampel jenuh dimana semua yang menjadi populasi dijadikan sampel (Fikri, 2021).

Metode penelitian kuantitatif dapat diartikan sebagai metode penelitian yang berlandaskan pada filsafat positivisme, digunakan untuk meneliti pada populasi atau sampel tertentu (Prof. Dr. Sugiyono, 2015).

Data yang digunakan dalam penelitian ini adalah data sekunder yang berasal dari annual report yang dapat diakses melalui website Otoritas Jasa Keuangan dalam bentuk deret waktu (time series) pertahun dari 2014-2020. Variabel yang digunakan adalah variabel bebas (independen) yang meliputi pembiayaan musyarakah serta variabel terikat (dependen) .meliputi pendapatan.

Teknik analisis data yang digunakan adalah uji asumsi klasik sederhana (uji normalitas, uji koifisien determinasi, dan uji t).

\section{HASIL DAN PEMBAHASAN A.Hasil Uji Statistik 1. Uji Tes Normalitas}

Tabel 4.1

\begin{tabular}{|c|c|c|c|c|c|c|}
\hline \multicolumn{8}{|c|}{ Tests of Normality } \\
\hline & \multicolumn{3}{|c|}{$\begin{array}{c}\text { Kolmogorov- } \\
\text { Smirnova }\end{array}$} & \multicolumn{3}{c|}{ Shapiro-Wilk } \\
\cline { 2 - 7 } & $\begin{array}{c}\text { Statist } \\
\text { ic }\end{array}$ & df & Sig. & $\begin{array}{c}\text { Statist } \\
\text { ic }\end{array}$ & df & Sig. \\
\hline $\begin{array}{c}\text { Pendapa } \\
\tan \end{array}$ &, 192 & 7 &, $200^{*}$ &, 922 & 7 &, 487 \\
\hline \multicolumn{7}{|c|}{ *. This is a lower bound of the true significance. } \\
\hline \multicolumn{6}{|c|}{ a. Lilliefors Significance Correction } \\
\hline
\end{tabular}

Sumber : olah data SPSS 22

Uji normalitas bertujuan untuk mengetahui residual data dari regresi linear memiliki distribusi normal atau tidak.

Dari tabel diatas menunjukkan bahwa data penelitian telah terdistribusi normal yang dibuktikan dengan asymp sig. Sebesar 0.200 yang lebih besar dari tingkat signifikansi penelitian 5\% $(\alpha=0.05)$ oleh karena itu data penelitian telah terdistribusi normal, data dapat digunakan dalam pengujian dengan model regresi berganda.

a. Uji Regresi Linear Sederhana

Tabel 4.2

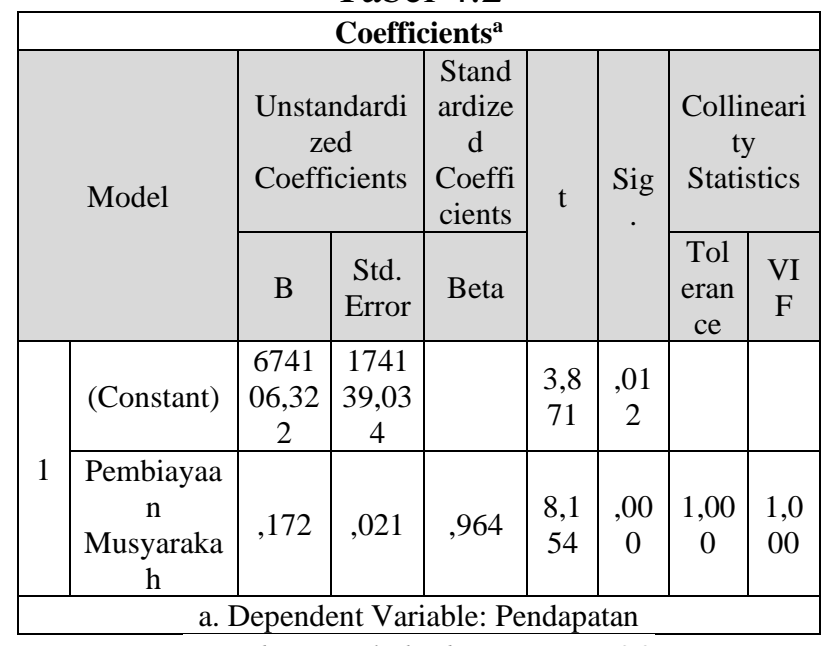

Sumber : olah data SPSS 22

Dari hasil pengujian diatas, maka menghasilkan model persamaan sebagai berikut : $\mathrm{Y}=\mathrm{a}+\mathrm{Bx}$

$\mathrm{a}=$ angka konstan dari Unstandardized Coifficients. Dalam kasus ini nilainya sebesar 674106,322. Angka ini merupakan angka konstan yang mempunyai arti bahwa variabel independen berada pada posisi tetap (X) maka nilai konsisten Pendapatan (Y) adalah sebesar 674106,322. 
$\mathrm{b}=$ angka koefisien regresi. Nilainya sebesar 0,172 . Angka ini mengandung arti bahwa setiap penambahan 1\% tingkat Pembiayaan Musyarakah (X), maka Pendapatan akan meningkat sebesar 0,172 .

Karena nilai koefisien regresi bernilai positif (+), maka dengan demikian dapat dikatakan bahwa Pembiayaan Musyarakah (X) berpengaruh positif terhadap Pendapatan (Y), sehingga persamaan regresinya adalah $\mathrm{Y}=674106,322+$ 0,172 .

b. Uji Koefisien Determinasi

Tabel 4.3

\begin{tabular}{|c|c|c|c|c|c|}
\hline \multicolumn{7}{|c|}{$\begin{array}{c}\text { Mod } \\
\text { el }\end{array}$} & $\mathrm{R}$ & $\begin{array}{c}\mathrm{R} \\
\text { Square }\end{array}$ & $\begin{array}{c}\text { Adjusted } \\
\text { R Square }\end{array}$ & $\begin{array}{c}\text { Std. Error } \\
\text { of the } \\
\text { Estimate }\end{array}$ & $\begin{array}{c}\text { Durbin- } \\
\text { Watson }\end{array}$ \\
\hline 1 &, $964^{\mathrm{a}}$ &, 930 &, 916 & $\begin{array}{c}195155,05 \\
6\end{array}$ & 1,818 \\
\hline \multicolumn{6}{|c|}{ a. Predictors: (Constant), Pembiayaan Musyarakah } \\
\hline \multicolumn{6}{|c|}{ b. Dependent Variable: Pendapatan } \\
\hline
\end{tabular}

Sumber : olah data SPSS 22

Tabel di atas menjelaskan nilai korelasi atau hubungan (R) yaitu sebesar 0,964 dan dijelaskan besar prosentase pengaruh variabel-variabel bebas terhadap variabel terikat yang disebut koefisien determinasi yang merupakan hasil dari penguadratan $\mathrm{R}$.

Dari output tersebut diperoleh koefisien determinasi (R2) sebesar 0,930 yang mengandung pengertian bahwa pengaruh variabel bebas terhadap variabel terikat (Partisipasi) adalah sebesar 93,0\% sedangkan sisanya dipengaruhi oleh variabel lain yang tidak diteliti oleh peneliti.

\section{c. Uji T}

Tabel 4.4

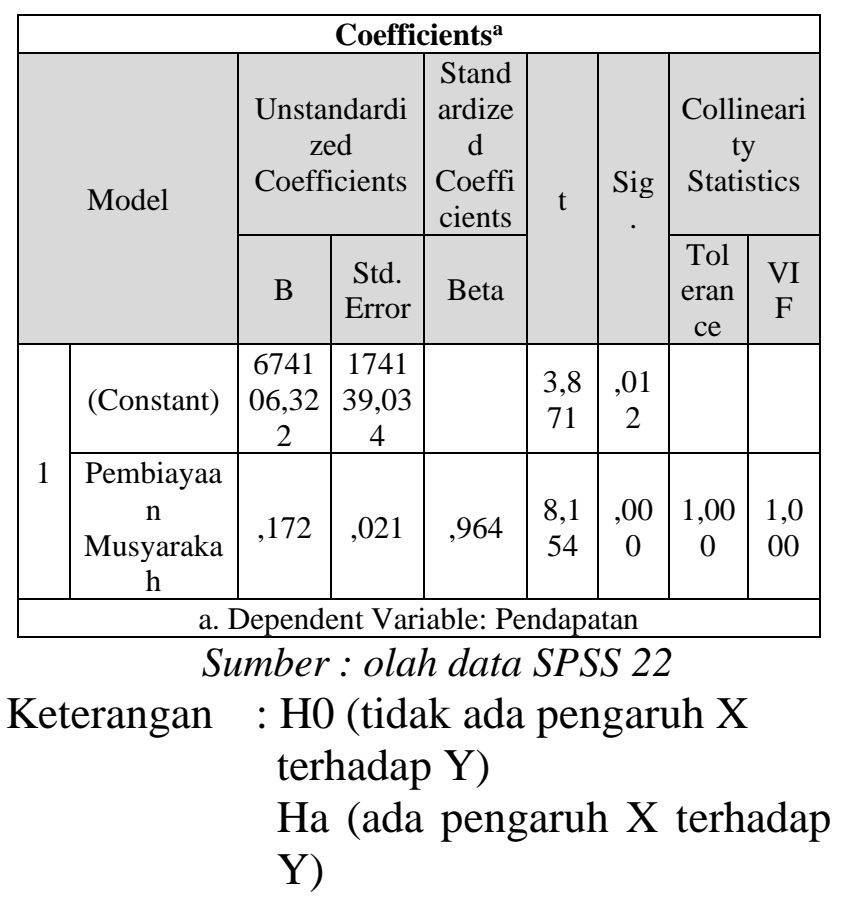

1. Jika nilai signifikasi (Sig) lebih kecil $<$ dari probabilitas 0,05 mengandung arti bahwa ada pengaruh $\mathrm{X}$ tehadap $\mathrm{Y}$.

2. Sebaliknya, jika nilai signifikasi (Sig) lebih besar > dari probabilitas 0,05 mengandung arti bahwa tidak ada pengaruh $\mathrm{X}$ terhadap Y

Berdasarkan output diatas diketahui nilai Sig sebesar 0,000 lebih kecil dari < 0,05. Sehingga dapat disimpulkan bahwa H0 ditolak dan Ha diterima, yang berarti bahwa ada pengaruh Pembiayaan Musyarakah (X) terhadap Pendapatan (Y).

\section{B. Pembahasan}

Berdasarkan hasil uji output nilai koefisien regresi bernilai positif sehingga persamaan regresinya adalah $\mathrm{Y}=674106,322+0,172$ dan hasil uji t nilai Sig sebesar 0,000 lebih kecil dari < 0,05. Sehingga dapat disimpulkan bahwa $\mathrm{H} 0$ ditolak dan $\mathrm{Ha}$ diterima, yang berarti bahwa ada pengaruh Pembiayaan Musyarakah (X) terhadap Pendapatan (Y), dan hasil uji koefisien determinasi (R2) sebesar 0,930 yang mengandung pengertian bahwa variabel pembiayaan musyarakah berpengaruh terhadap variabel pendapatan sebesar 93,0\%, sedangkan sisanya $7 \%$ 
dipengaruhi oleh variabel lain yang tidak diteliti oleh peneliti saat ini. Hasil penelitian ini memperkuat penelitian sebelumnya yang dilakukan oleh (Destiana, 2016).

\section{KESIMPULAN}

Berdasarkan dari hasil analisis data dan pembahasan diatas, didapatakan nilai koefisien regresi persamaannya adalah $\mathrm{Y}=$ $674106,322+0,172$ dan hasil uji t nilai Sig sebesar 0,000 lebih kecil dari $<0,05$ dan hasil uji koefisien determinasi (R2) sebesar 0,930 yang mengandung pengertian bahwa variabel pembiayaan musyarakah berpengaruh terhadap variabel pendapatan bank BRI Syariah Indonesia sebesar 93,0\%, sedangkan sisanya $7 \%$ dipengaruhi oleh variabel lain yang tidak diteliti oleh peneliti saat ini.

\section{DAFTAR PUSTAKA}

Antonio, M. S. (2001). Bank Syariah Dari Teori Ke Praktik (ke-1). GEMA INSANI.

Asiyah, B. N. (2019). Manajemen Pembiayaan Bank Syariah (Ke-1). KALIMEDIA.

Chefi Abdul Latif. (2020). PEMBIAYAAN MUDHARABAH DAN PEMBIAYAAN MUSYARKAH DI PERBANKAN SYARIAH. 2.

Destiana, R. (2016). Analisis Dana Pihak Ketiga dan Risiko Terhadap Pembiayaan Mudharabah dan Musyarakah Pada Bank Syariah di Indonesia. LOGIKA Jurnal Ilmiah Lemlit Unswagati Cirebon, 17(2), 42-54.

Ditha Nada Pratama, Lia Dwi Martika, T. R. (2017). Profitability. Industrial Management and Data Systems, 3(1), 53-68.

https://doi.org/10.1108/0263557021042 8311

Fikri, P. M. (2021). Paisal Muhamad Fikri,
Wirman/ Pengaruh Pembiayaan Mudharabah Dan Musyarakah Terhadap Profitabilitas Pengaruh Pembiayaan Mudharabah Dan Musyarakah Terhadap Profitabilitas. Competitive Jurnal Akuntansi Dan Keuangan, 5(2), 2021.

Hidayatullah, M. S. (2020). Implementasi Akad Berpola Kerja Sama Dalam Produk Keuangan Di Bank Syariah (Kajian Mudharabah Dan Musyarakah Dalam Hukum Ekonomi Syariah). Jurnal Hadratul Madaniyah, 7(1), 34-41. https://doi.org/10.33084/jhm.v7i1.1613

Jamaludin, J., Syariah, P., Syariah, M. K., Ristanti, A., \& Syariah, P. (2021). Persepsi Dan Preferensi Terhadap Sikap Nasabah. 2, 61-76.

Lumingkewas, V. A. (2013). Pengakuan Pendapatan dan Beban Atas Laporan Keuangan Pada PT. Bank Sulut. Journal of Chemical Information and Modeling, 53(9), 1689-1699.

Nawawi, A., \& Nurdiansyah, D. H. (2018). Pengaruh Pembiayaan Mudharabah dan Musyarakah Terhadap Profitabilitas ( ROA ) Pada BPRS HIK Bekasi Kantor Cabang Karawang. 3, 96-104.

Prof. Dr. Sugiyono. (2015). Metode Penelitian Pendidikan (Prof. Dr. Sugiyono (ed.); 22nd ed.). ALFABETA .cv.

Putra, P. (2018). Pengaruh Pembiayaan Mudharabah, Musyarakah, Murabahah, Dan Ijarah Terhadap Profitabilitas 4 Bank Umum Syariah Periode 2013-2016. Jurnal Organisasi Dan Manajemen, 14(2), 140-150. https://doi.org/10.33830/jom.v14i2.159. 2018

Rohmi，P. K. (2020). Implementasi Akad Musyarakah Mutanaqishah Pada Pembiayaan Kepemilikan Rumah Di 
Bank Muamalat Lumajang. Iqtishoduna, 5(1), 17-37.

Sari, C. I. P., \& Sulaeman, S. (2021). Pengaruh Pembiayaan Murabahah, Pembiayaan Mudharabah dan Pembiayaan Musyarakah Terhadap Profitabilitas. Al Maal: Journal of Islamic Economics and Banking, 2(2), 160.

https://doi.org/10.31000/almaal.v2i2.311 1

Wahyuningsih, I. (2018). Pengaruh Pendapatan Pembiayaan Mudharabah terhadap Profitabilitas (ROA) pada PT. Bank Muamalat Indonesia Tbk. Periode 2011-2015. Tasharruf: Journal Economics and Business of Islam, 2(2), 186-211.

https://doi.org/10.30984/tjebi.v2i2.529 